\title{
Augustine and Wittgenstein: an Alleged Disagreement on Signs
}

\author{
Ivan Lapshin \\ Department of Ethics \\ Faculty of Humanities and Social Sciences \\ Peoples' Friendship University of Russia \\ Miklukho-Maklaya str., 10/2, Moscow, Russia 117198
}

\begin{abstract}
Ludwig Wittgenstein is often described as one of the greatest philosophers of the 20th century and the author of the first comprehensive theory of linguistic reference. Since Wittgenstein is often perceived this way, his theses are usually compared with other philosophers' ideas concerning language as if they were absolutely new. However, some ideas very similar to Wittgenstein's were first formulated much earlier. One of the most prominent pedagogical Augustine's concepts implied that it is impossible to teach someone words using words as well as signs using signs. Nevertheless, Wittgenstein argued with Augustine in one of his works as if the letter was the supporter of ostensive theory. After revealing some historical misunderstandings it becomes clear that there is no contradiction between two great philosophers on these general questions. However, a closer study shows that there is more to the question than it usually seems and there are several important points preceding the concepts of Augustine and Wittgenstein.
\end{abstract}

Keywords-Augustine; Wittgenstein; De Magistro; ostensive theory; reference theory

\section{INTRODUCTION}

Philosophy of language is still one of the most popular fields of analytic philosophy today. From the beginning of the $20^{\text {th }}$ century and on, analytic philosophers developed several theories concerning language, sense and denotation, symbolic logic etc. This part of modern philosophy already has its own history, but some of its aspects are usually described inaccurately. Ludwig Wittgenstein, one of the most prominent philosophers of the $20^{\text {th }}$ century, is often depicted as the most notable opponent of the ostensive theory whose writings refuted Augustine's concept of teaching through signs. This article aims to refine some important historical facts and to prove that, contrary to the common belief, Augustine and Wittgenstein were following the same lines of reasoning concerning language and ostensive teaching.

\section{Augustine's De MAgistro AND THE PROBLEM OF OSTENSIVE TEACHING}

The end of the XIX $^{\text {th }}$ century is traditionally considered as the time when semiotics and the early theories of the sign first appeared. And even though the word "semiotics" was first used by John Locke two centuries earlier, his Essay Concerning Human Understanding only charted this field of knowledge. This is why it's quite reasonable to associate it with de Saussure, Peirce, Frege, Husserl and their critics. However, there were much earlier attempts of theorizing in this sphere.

One of the first attempts to build a theory of the sign was Augustine's De doctrina christiana. Augustine's purpose was rather theological than philosophical: he tried to justify the allegorical method of biblical interpretation. However, while pursuing this goal, Augustine proposed several theses connected with the philosophy of language and sign: a sign can have several meanings; the interpretation of the sign should be based on the context, the literal meaning can coexist with the figurative, etc. [1, P. 298]. Some of these theses sound obvious today, but fifteen centuries earlier they were seen differently.

Augustine's dialogue On the Teacher (De Magistro) looks much more interesting for the modern philosophy. Reflecting on words and signs, Augustine and his son Adeodatus come to the conclusion that signs are intended to teach and to learn and therefore every sign must designate some object - something that exists. But then Augustine asks Adeodatus to explain single words in a random sentence: particularly, the meaning of "if", and it confuses Adeodatus. Then Augustine asks him to explain the meaning of "nothing". The obvious answer- "that which doesn't exist" - makes him admit that some signs don't correspond to something that exists. "What are we to do then? Unless we say that this word designates not that which doesn't really exist but the state of our mind when it doesn't see it but at the same time finds (or thinks that finds) that it doesn't exist" (2.3). So, concludes Augustine, at least some signs don't designate something that exists.

A preliminary conclusion of De Magistro can be the following: the signs themselves don't teach, they can point at something we can remember or, if we don't remember anything, they are useless [2, P. 406]. "This is a truthful and solid argument: when words are spoken we either know what they signify or we don't; if we know, then it's reminding rather than learning; but if we don't know, it isn't even reminding, though perhaps we recollect what we should inquire... Regarding each of the things we understand, 
however, we don't consult a speaker who makes sounds outside us, but the Truth that presides within over the mind itself, though perhaps words prompt us to consult Him" (11.36). Augustine here gets very close to the idea of Plato's anamnesis, talking of knowledge as of recollection and metaphysical illumination. The final conclusion, as it often happens in Augustine's works, looks like he turns from philosophy to theology: signs are useless if mind doesn't contemplate things, and such contemplation is impossible without admonition of God (the word "Teacher" in the title obviously implies "God") [3, P.70]. However, this move was natural for Augustine since he made no discernment between philosophy and theology.

Augustine's orientation towards the problems of perception of language can also be seen easily in other aspects of his philosophy. For example, denying the substantiality of evil, Augustine explains his thought quite in the spirit of linguistic philosophy: we call a drought a drought and not the absence of rain because it's how language works and not because it really exists [4, P. 137]. We can't conclude the existence of a thing from the existence of a notion.

Unfortunately, Augustine and his ideas were almost entirely ignored by the linguistic philosophers during the $20^{\text {th }}$ century, despite the fact that they were occupied with similar questions. Ludwig Wittgenstein was almost the only exception-he argued with Augustine in his books (and surprised the members of Vienna Circle with his interest in chronologically or thematically distant philosophers-in Heidegger, for example, a very questionable author for them). Besides, Wittgenstein's teacher and friend Bertrand Russell also showed an apparent interest in Augustine and dedicated a chapter of A History of Western Philosophy to him.

\section{EARly Augustine AND Late Wittgenstein: VIEWS AND METHODS}

The sum of late Wittgenstein's ideas, Philosophical Investigations, starts with the quote from Confessiones in which Augustine postulates the existence of "natural language" ("natural words") and also formulates the ostensive theory of teaching language in its general form: children learn language by hearing words and by seeing the adults pointing or looking at the corresponding things. First paragraphs of Philosophical Investigations are dedicated to the criticism of this idea. In short, this criticism was expounded by Wittgenstein in the Brown Book: "Augustine, in describing his learning of language, says that he was taught to speak by learning the names of things. It is clear that whoever says this has in mind the way in which a child learns such words as "man", "sugar", "table", etc. He does not primarily think of such words as "today", "not", "but", "perhaps"" [5, P. 77].

This quote should sound surprising to those readers of Wittgenstein who are familiar with Augustine's works. Wittgenstein assumed that Augustine didn't take into account the existence of auxiliary parts of speech. But in De Magistro exactly their existence is used to show that at least some signs can't be explained severally and out of context - the thesis which Wittgenstein himself would agree with. Furthermore, holding that signs themselves can't teach us anything and can't "bring" us to things, Augustine proves to be close to Wittgenstein: the latter asserted in his Tractatus Logico-Philosophicus that the world consists of facts, not of things, and language expresses facts, not things. Moreover, it is no exaggeration to say that, in general, the main theses in which Wittgenstein criticized the ostensive theory were already formulated in Augustine's De Magistro.

It is also remarkable how similar these two authors, being mutually chronologically far, express their thoughts. Some of Augustine's works are dialogues but the role of the companion in them is usually formal, or he asks the questions that serve only to clarify and prove Augustine's ideas and are obviously forged by Augustine himself. Many Augustine's works, even those which are not dialogues in the strict sense, are composed according to the following scheme: Augustine proposes a thesis and suggests that one could object somehow (or his companion objects). Then, Augustine would answer so-and-so, which also could be objected etc. It is as if Augustine were playing chess with himself, thinking over both his and his opponent's move. But the Philosophical Investigations are written in the same way: Wittgenstein considered this way as the most appropriate to express his late views. For example, cf. $\S \S 98-99$ of the Philosophical Investigations: "So there must be perfect order even in the vaguest sentence. The sense of a sentence-one would like to say-may, of course, leave this or that open, but the sentence must nevertheless have a definite sense. An indefinite sense - that would really not be a sense at all.This is like: An indefinite boundary is not really a boundary at all. Here one thinks perhaps: if I say "I have locked the man up fast in the room - there is only one door left open"then I simply haven't locked him in at all; his being locked in is a sham. One would be inclined to say here: "You haven't done anything at all". An enclosure with a hole in it is as good as none.-But is that true?"

But this Augustine's "playing" both for himself and his opponent makes him close not only to Wittgenstein. The above-mentioned De Magistro as well as some other Augustine's works is, in fact, a dialogue, but a dialogue that resembles Plato's: the answers of Adeodatus usually convey almost no meaning and are nothing but "yes, certainly", "assuredly" etc. - as well as Aristotle's answers in Plato's Parmenides. In other dialogues Augustine's companions ask leading questions or propose obviously untenable theses the fallacy of which is then revealed by Augustine. This method of writing reminds of the Philosophical Investigations and, again, of maieutics in Plato's dialogues. We can hardly say that this is the direct influence of Augustine but, in a sense, he connects Plato with Wittgenstein methodologically.

It is also worth noting that Augustine in De Magistro substantiates the method of Socrates' maieuthics indirectly and thus shows that the efficacy of the maieutic approach in some cases and it's inconsistency in some other cases prove his main thesis on signs: "Now it often happens that someone denies something when questioned about it, and is brought around by further questions to admit it. This happens because of the weakness of his discernment. He can't consult 
that light regarding the whole matter. Yet he is prompted to do it part-by-part when he's questioned about the very parts that make up the whole, which he didn't' have the ability to discern. If he's guided in this case by the words of his questioner, the words nevertheless do not teach him, but they raise questions in such a way that he who is questioned learns within, corresponding to his ability to do so" (12.40).

Therefore, the views of Augustine and Wittgenstein concerning the questions of language and sign were similar in many aspects. There can be no doubt that Wittgenstein would agree with Augustine's brilliant thought that "discussing words with words is as entangled as interlocking and rubbing the fingers with the fingers, where it may be scarcely distinguished, except by the one who does it, which fingers itch and which give aid to the itching" (5.13). It is also doubtless though that Wittgenstein certainly disagreed with the thesis that was indirectly proposed in Confessiones. But in Confessiones Augustine was concerned with his introspections, he aimed to explain his conditions during several periods of his live. Although his point of view in Confessiones is fixed - it's the point of view of the mature Augustine, at least some of his metaphors and explanations could be anachronistic and not depicting the ideas of the mature Augustine. As we could see in De Magistro, Augustine was an opponent rather than an advocate of the ostensive theory of teaching language and it was hardly possible that to the time he wrote Confessiones (i.e. 10 years later) this theory ceased to be unconvincing to him.

\section{CONCLUSION}

Augustine's impact on European philosophy was undoubtedly profound in general, but this impact was sporadic both chronologically and thematically. The fact that many of Augustine's works were translated to modern European languages only in the $20^{\text {th }}$ century (and some of them still aren't translated) was not the last reason for it. Wittgenstein most likely didn't read De Magistro, but it would be unjust to consider it his fault: apparently, first English and German translations of De Magistro were printed after the Philosophical Investigations were finished. Maybe this was the reason why Wittgenstein popularized a casual idea of Augustine and not the theories he worked on hard and systematically. Nevertheless, there was hardly another philosopher in the $20^{\text {th }}$ century that illuminated this aspect of Augustine's philosophy as greatly as Wittgenstein.

\section{REFERENCES}

[1] Stoyanoff, Stacy J. Language Learning Theory: A Comparison between Wittgenstein and Augustine's De Magistro // Philosophy of Education. University of Illinois at Urbana-Champaign, 1998.

[2] Anderson, Robert D.. Teaching Augustine's On the Teacher // Religions. №6, 2015.

[3] Mooney, T.B. and Nowacki, M. Understanding Teaching and Learning: Classic Texts on Education by Augustine, Aquinas, Newman and Mill. Exeter, Imprint Academic, 2011.

[4] Lapshin, Ivan Y. Aesthetics of Order in the Teaching of Augustine [Estetika poryadka v uchenii Blazhennogo Avgustina] // Historical, Philosophical, Political and Law Sciences, Culturology and Study of Art. Issues of Theory and Practice. Moscow, 2012.
[5] Wittgenstein, L. The Blue and Brown Books. Oxford: Blackwell, 1958.

[6] Moran, S. A stranger in a strange land: ostensive language acquisition in cyberspace. Seán Moran // Efektivní využití techniky a softwaru při výuce cizích jazyků. Prague, 2008. 